\title{
HUBUNGAN KONDISI DAN PERILAKU PEMANFAATAN SANITASI DASAR DENGAN KEJADIAN DIARE PADA BALITA DI DESA KECILA KECAMATAN KEMRANJEN KABUPATEN BANYUMAS
}

\author{
Rusbandini Warastuti $^{1)}$, Suparmin ${ }^{2)}$, Teguh Widiyanto ${ }^{3)}$ \\ Jurusan Kesehatan Lingkungan, Politeknik Kesehatan Kemenkes Semarang, \\ Jl.Raya Baturaden KM 12 Purwokerto, Indonesia
}

\begin{abstract}
ABSTRAK
Penyakit diare terkait erat dengan kondisi lingkungan khususnya sanitasi dasar dan pemanfaatannya. Desa Kecila merupakan salah satu desa di wilayah Puskesmas I Kemranjen dengan kasus diare tertinggi. Penelitian ini bertujuan untuk mengetahui hubungan kondisi dan pemanfaatan sanitasi dasar dengan kejadian penyakit diare pada balita di Desa Kecila Kecamatan Kemranjen Kabupaten Banyumas. Penelitian menggunakan metode case control dengan pendekatan retrospektif. Sampel kasus diambil secara total sampling dari ibu balita yang menderita diare sebanyak 52 orang dan sampel kontrolnya diambil dari ibu balita yang rumahnya berdekatan dengan sampel kasus sebanyak 52 orang. Analisis data menggunakan uji chi square. Hasil penelitian diketahui ada hubungan antara kondisi sumber air bersih $(p=0,03$; $O R=3,60)$, kondisi pembuangan air limbah $(p=0,00 ; O R=10,967)$, kondisi jamban keluarga $(p=0,00$; $O R=11,111)$, dan perilaku pemanfaatan sanitasi dasar $(p=0,00 ; O R=12,960)$ dengan kejadian diare pada balita di Desa Kecila Kecamatan Kemranjen Kabupaten Banyumas. Kondisi dan pemanfaatan sanitasi dasar berhubungan dengan kejadian diare pada balita. Warga masyarakat lebih memperhatikan kondisi lingkungan rumah yang baik, dengan membersihkan SPAL agar dapat berfungsi baik, menggunakan jamban leher angsa dan membersihkan jamban minimal 1 kali seminggu mencuci tangan sebelum memberikan makan anaknya, air yang dikonsumsi selalu di masak terlebih dahulu dan peralatan makan dan minum di cuci dari air yang mengalir.
\end{abstract}

Kata Kunci : Sanitasi Dasar, Perilaku, Diare, Balita

\begin{abstract}
[CORRELATION OF CONDITIONS AND BEHAVIOR USE OF BASIC SANITATION WITH EVENTS OF DIARRHEA IN CHILDREN IN THE KECILA VILLAGE KEMRANJEN DISTRICT BANYUMAS REGENCY]

Diarrhea disease is closely related to basic sanitation in particular environmental conditions and usage. Even a small village is a village in the region of Puskesmas I Kemranjen with the highest cases of diarrhea. This study aims to determine the relationship between the condition and utilization of basic sanitation with the incidence of diarrheal disease in infants in even a small village Kemranjen District of Banyumas. Research using observational method with retrospective case control approach. Samples taken in the case of total sampling of mothers who suffer from diarrhea as many as 52 people and control samples taken from mothers whose house is adjacent to the sample of cases as many as 52 people. Data analysis using chi square test. The survey results revealed no correlation between the condition of clean water sources $(p=0.03$; OR $=$ 3.60), the condition of wastewater discharge ( $p=0.00 ; O R=10.967)$, the condition of household toilets $(p=$ $0.00 ; O R=11.111)$, and utilization of basic sanitation behavior $(p=0.00 ; O R=12,960)$ and the incidence of diarrhea in infants in even a small village Kemranjen District of Banyumas. Basic sanitation conditions and utilization associated with the incidence of diarrhea in infants. Initially, people pay more attention to environmental conditions good house cleaning, with SPAL in order to function well, latrines goose neck and clean latrines at least 1 times a week to wash their hands before feeding their children, water consumption is always cooked in advance and eating utensils and drinking in washing of the flowing water.
\end{abstract}

Keywords : Basic Sanitation, Behavior, diarrhea, Toddler

\section{PENDAHULUAN}

Penyakit menular di Indonesia masih merupakan salah satu masalah di bidang kesehatan. Hal ini disebabkan oleh keadaan lingkungan dan perilaku

1) Email : sofia15.wr@gmail.com

2) Email : pakparmin@yahoo.com

3) Email : widiyantoteguh@yahoo.co.id masyarakat yang tidak menguntungkan. Salah satu penyakit menular yang merupakan masalah kesehatan di Indonesia adalah diare, dimana angka kesakitan yang tinggi dan berpotensi menyebabkan kematian terutama jika pengobatan penderita terlambat 
dilakukan. Diare merupakan salah satu gejala dari penyakit pada sistem gastrointestinal atau penyakit lain di luar saluran pencernaan. Diare adalah keadaan frekuensi buang air besar lebih dari 4 kali pada bayi dan lebih dari 3 kali pada anak, dengan konsistensi feses encer, berwarna hijau atau dapat pula bercampur lendir (Ngastiyah, 2005).

Anak-anak yang menderita diare lebih dari 12 kali pertahun di negara Amerika Utara (Pitono dkk, 2006). Prevalensi tertinggi terdeteksi diare pada anak balita (1-4 tahun) di Indonesia, yaitu 16,7\%. Prevalensi diare menurut jenis kelamin untuk laki-laki dan perempuan hampir sama, yaitu 8,9\% pada laki-laki dan 9,1\% pada perempuan (Kemenkes RI, 2012). Kejadian Luar Biasa (KLB) kasus diare pada tahun 2010 sebesar 31.676 kasus dengan angka kematian sebesar 324 orang. Pada tahun 2011 sebesar 27.003 kasus dengan angka kematian sebesar 290 orang. Jumlah kasus diare dalam KLB pada tahun 2012 sebesar 14.800 kasus dengan angka kematian sebesar 245 orang. Prevalensi diare klinis adalah 9,0\% (rentang: 4,2\% 18,9\%)(Kemenkes RI, 2012). Penemuan penderita diare Provinsi Jawa Tengah tahun 2011 sebesar 57,89\% (Dinkes Prop. Jateng, 2012). Menurut data dari Dinas Kesehatan Kabupaten Banyumas, kasus diare di Kabupaten Banyumas selama tahun 2012 mencapai 82.145 kasus.

Studi pendahuluan yang dilakukan di Puskesmas I Kemranjen diketahui bahwa kasus diare di Puskesmas I Kemranjen di tahun 2015 sebanyak 541 kasus dan 1 kasus meninggal dunia. Dari 541 kasus, 194 kasus terjadi pada balita. Tiga desa dari 8 desa di wilayah Puskesmas I Kemranjen yang kasus diarenya tertinggi adalah Kecila sebanyak 52 kasus, Sibalung 36 kasus, dan Petarangan 35 kasus (Puskesmas I Kemranjen, 2015).

Balita yang menderita diare akan kehilangan cairan dan elektrolit yang secara mendadak dapat mengakibatkan berbagai macam komplikasi diantaranya yaitu dehidrasi, kejang akibat volume darah berkurang, malnutrisi energi protein dan kematian (Nelson, 2000). Model segitiga epidemiologi menurut Gordon (dalam Subaris \& Kristiawan, 2009) menggambarkan interaksi tiga komponen penyebab penyakit yaitu: Manusia (host), Penyebab/bibit penyakit (agent), dan lingkungan (environment). Penyakit dapat terjadi karena adanya interaksi ketiga komponen tersebut.

Hasil Riset Kesehatan Dasar tahun 2013 menunjukkan bahwa rumah tangga yang memiliki akses ke fasilitas sanitasi 'improved' juga meningkat dari 40,3 persen (2007) menjadi 59,8 persen (2013). Proporsi RT yang memiliki akses terhadap sumber air minum improved di Indonesia adalah sebesar 66,8 persen (perkotaan: 64,3\%; perdesaan: 69,4\%). Proporsi RT di Indonesia menggunakan fasilitas BAB milik sendiri adalah 76,2 persen, milik bersama sebanyak 6,7 persen, dan fasilitas umum adalah 4,2 persen. Masih terdapat RT yang tidak memiliki fasiltas BAB atau
BAB sembarangan, yaitu sebesar 12,9 persen (Kemenkes RI, 2013).

Penyakit diare terkait erat dengan kondisi lingkungan. Keluarga yang menggunakan sumber air minum dari sumur gali di Desa Kecila mencapai 53,0\%. Rumah dengan Saluran Pembuangan Air Limbah yang memenuhi syarat baru sebanyak 34,4\%. Rumah yang sudah memiliki jamban keluarga sebesar 42,2 \% (Puskesmas I Kemranjen, 2014). Hasil penelitian yang dilakukan oleh Adisasmito (2007) menyimpulkan bahwa faktor risiko diare menurut faktor ibu adalah: pengetahuan, perilaku dan hygiene ibu. Faktor risiko diare menurut faktor anak: status gizi, dan pemberian ASI eksklusif. Faktor lingkungan berdasarkan sarana air bersih (SAB), yang lebih banyak diteliti adalah jenis $\mathrm{SAB}(\mathrm{OR}=3,19)$, risiko pencemaran SAB $(\mathrm{OR}=7,89)$, sarana jamban (OR=17,25). Penelitian lain oleh Gustiana (2013) menyimpulkan adanya hubungan antara variabel independen (perilaku ibu, pengetahuan, sikap, dan tindakan ibu) dengan variabel dependen (kejadian diare pada balita).

Mengingat masalah sanitasi merupakan masalah penting yang berhubungan dengan penyakit berbasis lingkungan yang salah satunya adalah penyakit diare, maka peneliti tertarik untuk meneliti tentang hubungan kondisi sanitasi dasar yang meliputi sumber air, sarana pembuangan air limbah dan sarana jamban keluarga serta perilaku pemanfaatan sarana sanitasi dasar dengan kejadian penyakit diare pada balita di Desa Kecila Kecamatan Kemranjen Kabupaten Banyumas.

Penelitian ini bertujuan untuk mengetahui hubungan kondisi dan perilaku pemanfaatan sanitasi dasar dengan kejadian kejadian diare pada balita di Desa Kecila Kecamatan Kemranjen Kabupaten Banyumas.

\section{METODE PENELITIAN}

Jenis penelitian observasional dengan pendekatan case control retrospektif yaitu jenis penelitian dimana subyek penelitian atau kasus sudah terjadi sebelum dimulainya penelitian. Penelitian ini dilaksanakan di Desa Kecila Kecamatan Kemranjen Kabupaten Banyumas. Populasi dalam penelitian ini adalah semua ibu balita di Desa Kecila Kecamatan Kemranjen Kabupaten Banyumas tahun 2016. Sampel penelitian ini terdiri dari sampel kasus dan sampel kontrol yang diambil dengan perbandingan $1: 1$, artinya jumlah sampel kasus sama banyaknya dengan jumlah sampel kontrol. Sampel kasus diambil secara total sampling dari ibu balita yang menderita diare sebanyak 52 orang dan sampel kontrolnya diambil dari ibu balita yang rumahnya berdekatan dengan sampel kasus sebanyak 52. Teknik pengambilan sampel untuk sampel kasus menggunakan teknik total sampling yaitu seluruh anggota populasi diambil menjadi sampel penelitian dan untuk sampel kontrol menggunakan teknik purposive sampling yaitu pengambilan sampel dengan pertimbangan tertentu, yaitu rumahnya 
berdekatan dengan sampel kasus dan balita tidak menderita diare. Pengumpulan data tentang kondisi sanitasi dasar, perilaku pemanfaatan sanitasi dasar serta kejadian penyakit diare menggunakan lembar observasi dan kuesioner. Data kondisi sanitasi dasar dengan mengobservasi langsung sanitasi dasar rumah ibu balita. Data perilaku pemanfaatan sanitasi dasar menggunakan kuesioner. Responden sebelumnya dimintai persetujuan menjadi responden. Data primer diambil menggunakan check list dan kuesioner. Data sekunder didapat melalui dokumentasi catatan rekam medis puskesmas dan data profil Desa Kecila. Analisis univariat digunakan untuk mengetahui kondisi dan perilaku pemanfaatan sarana sanitasi dasar serta kejadian diare menggunakan analisis univariat. Analisis bivariat digunakan untuk mengetahui hubungan antara variabel bebas (kondisi dan perilaku pemanfaatan sanitasi dasar) dengan variabel terikat (kejadian diare). Untuk mencari hubungan antar variabel digunakan uji Chi-Square. Untuk mengetahui derajat hubungan digunakan Odds ratio (OR).

\section{HASIL PENELITIAN DAN PEMBAHASAN}

\section{A. Hasil Analisis Univariat}

Berdasarkan pada hasil analisis univariat diperoleh deskripsi data hasil penelitian yang meliputi kondisi sanitasi dasar (sumber air bersih, pembuangan air limbah, jamban keluarga, perilaku pemanfaatan sanitasi dasar dan kejadian diare sebagai berikut.

Tabel 1. Hasil Analisis Univariat

\begin{tabular}{|c|l|l|c|c|}
\hline No & \multicolumn{1}{|c|}{ Variabel } & Kategori & Jml & $\%$ \\
\hline 1 & \multirow{2}{*}{$\begin{array}{l}\text { Sumber air } \\
\text { bersih }\end{array}$} & Cukup baik & 16 & 15,4 \\
\cline { 3 - 5 } & & Baik & 88 & 84,6 \\
\hline 2 & \multirow{2}{*}{$\begin{array}{l}\text { Pembuangan } \\
\text { air limbah }\end{array}$} & Cukup baik & 33 & 31,7 \\
\cline { 3 - 5 } & Jamban & Baik & 71 & 68,3 \\
\cline { 3 - 5 } & keluarga & Baik & 75 & 72,1 \\
\hline 4 & \multirow{2}{*}{$\begin{array}{l}\text { Perilaku } \\
\text { pemanfaatan }\end{array}$} & Cukup baik & 31 & 29,8 \\
\cline { 3 - 5 } & sanitasi dasar & Baik & 73 & 70,2 \\
\hline 5 & $\begin{array}{l}\text { Kejadian } \\
\text { Diare }\end{array}$ & Diare & 52 & 50,0 \\
\cline { 3 - 5 } & Tidak Diare & 52 & 50,0 \\
\hline
\end{tabular}

Sumber: Data Primer Diolah (2016)

1. Sumber air bersih

Responden yang diteliti sebanyak 104 rumah, yang kondisi sumber air bersih dalam kategori baik sebanyak 88 rumah $(84,6 \%)$ dan yang cukup baik sebanyak 16 rumah $(15,4 \%)$.

Sumber air rumah tangga di Desa Kecila yang sebagian besar dalam kategori baik, dapat disebabkan karena di setiap rumah tangga sudah tersedia sumber air bersih milik sendiri yang kebanyakan dari sumur gali. Pembuatan sumur gali tersebut kebanyakan juga telah memenuhi standar karena berjarak 10 meter dari sumber pencemaran seperti jamban atau pembuangan air limbah keluarga. Lahan yang umumnya masih tersedia luas di masyarakat pedesaan, sehingga memungkinkan masyarakat desa dapat membuat fasilitas sumber air bersih yang memenuhi persyaratan kesehatan.

Air bersih merupakan salah satu kebutuhan penting manusia dalam rangka mempertahankan hidupnya. Wisnu (1999), menyatakan bahwa air merupakan kebutuhan pokok bagi kehidupan manusia di bumi ini. Sesuai dengan kebutuhannya, air dipakai sebagai air minum, mandi dan mencuci, pengairan pertanian, kolam perikanan, sanitasi, transportasi baik sungai maupun laut.

Sumber air bersih masyarakat di pedesaan, termasuk di Desa Kecila kebanyakan adalah sumur gali, yang dibuat secara bergotong royong dengan anggota masyarakat lainnya. Notoatmodjo (2012), menyatakan bahwa masyarakat pada umumnya mendapatkan kebutuhan air bersih dari air sumur gali. Sarana air bersih adalah semua sarana yang dipakai sebagai sarana air bersih bagi pemenuhan rumah yang dipakai sehari-hari Notoatmodjo (2012.

Hasil penelitian Hamzah (2012), menunjukkan bahwa terdapat 82 responden (60,3\%) yang menggunakan air bersih yang memenuhi syarat. Hasil penelitian penelitian Bumulo (2012) juga menyatakan bahwa sarana penyediaan air bersih sebagian besar memenuhi syarat sebanyak 150 responden (57,9\%).

\section{Pembuangan air limbah}

Responden yang diteliti sebanyak 104 rumah, yang kondisi pembuangan air limbah dalam kategori baik sebanyak 71 rumah (68,3\%) dan yang cukup baik sebanyak 33 rumah (31,7\%).

Sarana pembuangan air limbah rumah tangga di Desa Kecila yang sebagian besar dinyatakan baik, dikarenakan sebagian besar rumah tangga sudah memiliki sarana pembuangan air limbah yang tertutup, kedap air dan dapat mengalirkan air dengan lancar. Fasilitas pembuangan air limbah harus dimiliki oleh setiap rumah tangga, agar kesehatan anggota keluarga dapat terjamin. Fasilitas pembuangan air limbah yang tidak memenuhi standar kesehatan dapat menjadi sarang nyamuk yang berisiko menularkan demam berdarah atau juga menjadi tempat hinggapnya lalat yang dapat menularkan penyakit diare, sakit perut dan penyakit lainnya.

Limbah rumah tangga harus dikelola sedemikian rupa agar tidak menjadi sumber penularan penyakit. Sarana pembuangan air limbah yang tidak memenuhi syarat akan menimbulkan bau, mengganggu estetika dan berpotensi menularkan penyakit. Bila ada saluran pembuangan air limbah di halaman, secara rutin harus dibersihkan, agar air limbah dapat mengalir (Kemenkes RI, 2011).

Hasil penelitian ini sejalan dengan penelitian Mansyah (2005) yang menyatakan bahwa kondisi tempat pencemaran air sebagian besar sesuai dengan standar sebanyak 34 orang (58,62\%). Hasil penelitian Hamzah (2012), juga diperoleh bahwa terdapat 57 responden (41,9\%) yang pengelolaan air limbahnya memenuhi syarat. 


\section{Jamban keluarga}

Responden yang diteliti sebanyak 104 rumah, yang kondisi Jamban keluarga dalam kategori baik sebanyak 75 rumah $(72,1 \%)$ dan yang cukup baik sebanyak 29 rumah (27,9\%).

Sarana jamban keluarga di Desa Kecila yang sebagian besar dinyatakan baik, dikarenakan mayoritas rumah tangga sudah memiliki fasilitas MCK yang dilengkapi dengan jamban, dimana sebagian besar menggunakan jamban model leher angsa, terdapat ventilasi dan penerangan yang cukup serta lantai jambannya kedap air.

Jamban merupakan fasilitas pembuangan yang harus dimiliki oleh setiap rumah tangga yang berfungsi sebagai penampung kotoran manusia atau tinja. Jamban yang memenuhi kriteria kesehatan akan sangat membantu keluarga untuk menjaga kesehatan anggota keluarganya. Sehingga dapat terhindar dari berbagai resiko penyakit seperti, diare, gatal-gatal, muntaber, dan lain sebagainya.

Notoatmodjo (2012), menyatakan bahwa jamban keluarga adalah salah satu bagian yang dipergunakan untuk membuang tinja atau kotoran manusia bagi keluarga yang lazim disebut kakus/WC jamban keluarga bermanfaat untuk mencegah terjadinya penularan penyakit dan pencernaan dari kotoran manusia. Adapun syarat jamban sehat adalah tidak berbau dan tinja tidak dapat dijamah oleh serangga dan tikus, tidak mencemari tanah sekitar, sudah dibersihkan, aman dipergunakan, dilengkapi dinding dan atap pelindung, cukup penerangan, lantai kedap air, jamban berbentuk leher angsa, tersedia alat pembersih jamban, lubang penampung kotoran tertutup.

Upaya penggunaan jamban mempunyai dampak yang besar dalam penurunan risiko terhadap penyakit diare. Keluarga yang tidak mempunyai jamban harus membuat jamban dan keluarga harus buang air besar di jamban. Keluarga harus memperhatikan hal-hal sebagai berikut: a). Keluarga harus mempunyai jamban yang berfungsi baik dan dapat dipakai oleh seluruh anggota keluarga. B). Bersihkan jamban secara teratur. C). Gunakan alas kaki bila akan buang air besar (Kemenkes RI, 2011).

Hasil penelitian ini sejalan dengan penelitian Fajriana (2012) yang menyatakan bahwa kualitas jamban dari 95 responden sebagian besar sehat sebanyak 84 responden (88,42\%), sedangkan yang memiliki jamban tidak sehat sebanyak 11 responden (11,57\%). Hasil penelitian Hamzah (2012), juga diperoleh bahwa terdapat 56 responden $(41,2 \%)$ yang menggunakan jamban yang memenuhi syarat.

\section{Perilaku pemanfaatan sanitasi dasar}

Responden yang diteliti sebanyak 104 orang, yang perilaku pemanfaatan sanitasi dasar dalam kategori baik sebanyak 73 orang $(70,2 \%)$ dan yang cukup baik sebanyak 31 orang (29,8\%).

Perilaku pemanfaatan sanitasi dasar keluarga balita di Desa Kecila yang sebagian besar dinyatakan baik, tidak lepas dari perilaku sehat yang ditunjukkan oleh rumah tangga balita dalam menggunakan air bersih yang cukup, mencuci tangan sebelum makan atau ketika tangan kotor, menggunakan jamban yang sehat, serta memiliki sarana pembuangan air limbah yang tertutup dan air dapat mengalir dengan baik.

Perilaku kesehatan merupakan salah satu aspek penting yang harus ditanamkan dalam setiap rumah tangga untuk memenuhi kebutuhan kesehatan. Menurut Katz (dalam Notoatmodjo, 2012), perilaku dilatarbelakangi oleh kebutuhan individu. Seseorang dapat berperilaku baik terhadap obyek demi pemenuhan kebutuhan.

Faktor hygiene dan sanitasi lingkungan, kesadaran orang tua balita untuk berperilaku hidup bersih dan sehat menjadi faktor yang penting dalam menurunkan angka kesakitan diare pada balita. Perilaku pemanfaatan sanitasi dasar mencakup beberapa perilaku yang lekat dengan kehidupan seharihari rumah tangga. Perilaku tersebut antara lain: menggunakan air bersih yang cukup, cuci tangan, menggunakan jamban, dan pembuangan air limbah (Kemenkes RI, 2011).

Hasil penelitian ini sejalan dengan penelitian Mansyah (2005) yang menyatakan bahwa faktor kebiasaan mencuci tangan dan merebus air sebagian besar baik sebanyak 33 orang (56,89\%). Hasil penelitian Hamzah (2012), juga diperoleh bahwa terdapat 52 responden $(38,2 \%)$ yang mempunyai kebiasaan baik mencuci tangan dengan air bersih dan sabun.

\section{Kejadian Diare}

Responden yang diteliti sebanyak 104 orang, yang mengalami kejadian diare pada balita sebanyak 52 orang $(50,0 \%)$ dan yang tidak diare sebanyak 52 orang $(50,0 \%)$.

Jumlah balita yang menderita diare dan tidak menderita diare yang jumlahnya sama, disebabkan karena pada penelitian ini menggunakan desain kasus kontrol. Namun dalam kenyataannya, balita di Desa Kecila sebagian besar tidak mengalami diare. Meskipun demikian, masalah diare pada balita berapapun jumlahnya tetap menjadi permasalahan yang harus mendapatkan penanganan secepatnya.

Diare merupakan salah satu penyakit yang lebih banyak disebabkan oleh kurangnya kebersihan lingkungan rumah tangga. Diare adalah keluarnya tinja cair lebih dari tiga kali/24 jam. Diare akut terjadi akut dan berlangsung paling lama 3-5 hari. Diare berkepanjangan berlangsung lebih dari 7 hari. Diare kronik berlangsung lebih dari 14 hari (Sudarmo, 2007).

Balita merupakan populasi yang sangat rentan menderita diare, karena belum kuatnya daya tahan tubuh serta belum sempurnanya organ pencernaan. Penyebab diare pada balita secara tidak langsung dikarenakan oleh beberapa faktor yang mempermudah atau mempercepat terjadinya diare seperti keadaan gizi, sanitasi lingkungan, perilaku hidup besih dan sehat, kependudukan, sosial ekonomi (Suharyono, 2008). 
Prevalensi diare lebih banyak di perdesaan dibandingkan perkotaan, yaitu sebesar $10 \%$ di perdesaan dan $7,4 \%$ di perkotaan. Persentase diare lebih rendah pada anak yang tinggal di rumah dengan fasilitas kakus sendiri (Kemenkes RI, 2011).

Hasil penelitian ini sejalan dengan penelitian Bumulo (2012) yang menyatakan bahwa sebagian besar balita tidak mengalami diare sebanyak 156 orang (60,2\%). Hasil penelitian Hamzah (2012), juga diperoleh bahwa sebagian besar anak tidak diare sebanyak 39 balita $(57,4 \%)$.

\section{B. Hasil Analisis Bivariat}

Analisis bivariat dilakukan untuk mengetahui hubungan kondisi sanitasi dasar dan perilaku pemanfaatan sanitasi dasar keluarga balita dengan kejadian diare pada balita di Desa Kecila Kecamatan Kemranjen Kabupaten Banyumas. Hasil analisis bivariat disajikan pada tabel berikut ini.

Tabel 2. Hasil Analisis Bivariat

\begin{tabular}{|c|c|c|c|c|c|c|c|c|c|}
\hline \multirow{3}{*}{ No } & \multirow{3}{*}{ Variabel } & \multirow{3}{*}{ Kategori } & \multicolumn{4}{|c|}{ Kejadian Diare } & \multirow{3}{*}{$\begin{array}{c}\mathrm{P} \\
\text { value }\end{array}$} & \multirow{3}{*}{ OR } & \multirow{3}{*}{ CI95\% } \\
\hline & & & \multicolumn{2}{|c|}{$\mathrm{Ya}$} & \multicolumn{2}{|c|}{ Tidak } & & & \\
\hline & & & $\mathrm{n}$ & $\%$ & $\mathrm{n}$ & $\%$ & & & \\
\hline \multirow[t]{2}{*}{1} & \multirow{2}{*}{$\begin{array}{l}\text { Sumber air } \\
\text { bersih }\end{array}$} & Cukup baik & 12 & 75,0 & 4 & 25,0 & \multirow[t]{2}{*}{0,03} & \multirow[t]{2}{*}{3,600} & \multirow[t]{2}{*}{$1,077-12,035$} \\
\hline & & Baik & 40 & 45,5 & 48 & 54,4 & & & \\
\hline \multirow[t]{2}{*}{2} & \multirow{2}{*}{$\begin{array}{l}\text { Pembuangan air } \\
\text { limbah }\end{array}$} & Cukup baik & 28 & 84,8 & 5 & 12,5 & \multirow[t]{2}{*}{0,000} & \multirow[t]{2}{*}{10,967} & \multirow[t]{2}{*}{$3,757-32,008$} \\
\hline & & Baik & 24 & 33,8 & 47 & 66,2 & & & \\
\hline \multirow[t]{2}{*}{3} & \multirow{2}{*}{$\begin{array}{l}\text { Jamban } \\
\text { keluarga }\end{array}$} & Cukup baik & 25 & 86,2 & 4 & 13,8 & \multirow[t]{2}{*}{0,000} & \multirow[t]{2}{*}{11,111} & \multirow[t]{2}{*}{$3,497-35,302$} \\
\hline & & Baik & 27 & 36,0 & 48 & 64,0 & & & \\
\hline \multirow[t]{2}{*}{4} & \multirow{2}{*}{$\begin{array}{l}\text { Perilaku } \\
\text { pemanfaatan } \\
\text { sanitasi dasar }\end{array}$} & Cukup baik & 27 & 87,1 & 4 & 12,9 & \multirow[t]{2}{*}{0,000} & \multirow[t]{2}{*}{12,960} & \multirow[t]{2}{*}{$4,079-41,176$} \\
\hline & & Baik & 25 & 34,2 & 48 & 65,8 & & & \\
\hline
\end{tabular}

Sumber: Data Primer Diolah (2016)

1. Hubungan kondisi sumber air bersih dengan kejadian diare pada balita

Berdasarkan pada tabel 2 diketahui bahwa sumber air bersih pada kategori cukup baik sebagian balita menderita diare (75,0\%) dan pada kategori baik sebagian besar balita tidak menderita diare $(54,4 \%)$. Hasil uji Chi Square diperoleh nilai $p$ value sebesar 0,03 yang lebih kecil dari $\alpha=0,05$ artinya ada hubungan antara kondisi sumber air bersih dengan kejadian diare pada balita di Desa Kecila Kecamatan Kemranjen Kabupaten Banyumas. Nilai OR sebesar 3,600 artinya balita yang tinggal di rumah dengan kondisi sumber air pada kategori cukup baik berisiko menderita diare 3,600 kali lebih besar dibandingkan balita yang tinggal di rumah dengan kondisi sumber air bersih yang baik.

Sumber air minum utama merupakan salah satu sarana sanitasi yang tidak kalah pentingnya berkaitan dengan kejadian diare. Sebagian kuman infeksius penyebab diare ditularkan melalui jalur fekal oral. Mereka dapat ditularkan dengan memasukkan ke dalam mulut, cairan atau benda yang tercemar dengan tinja, misalnya air minum, jari-jari tangan, dan makanan yang disiapkan dalam panci yang dicuci dengan air tercemar (Depkes RI, 2011).

Penularan kuman infeksius penyebab diare ditularkan melalui Face-Oral kuman tersebut dapat ditularkan bila masuk ke dalam mulut melalui makanan, minuman atau benda yang tercemar dengan tinja, misalnya jarijari tangan, makanan yang wadah atau tempat makanminum yang dicuci dengan air tercemar. Masyarakat yang terjangkau oleh penyediaan air yang benar-benar bersih mempunyai risiko menderita diare lebih kecil dibanding dengan masyarakat yang tidak mendapatkan air bersih.
Masyarakat dapat mengurangi risiko terhadap serangan diare yaitu dengan menggunakan air yang bersih dan melindungi air tersebut dari kontaminasi mulai dari sumbernya sampai penyimpanan di rumah (Kemenkes RI, 2011).

Hasil penelitian ini berbeda dengan penelitian sebelumnya yang dilakukan oleh Mansyah (2005), yang menyatakan bahwa faktor jenis sumber air berhubungan dengan kejadian diare pada balita. Penelitian lainya yang dilakukan oleh Hamzah (2012) juga diperoleh ada hubungan antara penggunaan air bersih dengan kejadian diare pada balita. Hasil penelitian Bumulo (2012), juga menyatakan ada hubungan antara sarana penyediaan air bersih dengan kejadian diare pada anak balita. Perbedaan penelitian ini dengan penelitian sebelumnya dapat disebabkan oleh sudah baiknya sumber air keluarga di Desa Kecila, sehingga sebagian besar balitanya juga tidak mengalami diare.

2. Hubungan kondisi pembuangan air limbah dengan kejadian diare pada balita

Berdasarkan pada tabel 2 diketahui bahwa kondisi pembuangan air limbah pada kategori cukup baik sebagian balita menderita diare $(84,8 \%)$ dan pada kategori baik sebagian besar balita tidak menderita diare (66,2\%). Hasil uji Chi Square diperoleh nilai $p$ value sebesar 0,000 yang lebih kecil dari $\alpha=0,05$ artinya ada hubungan antara kondisi pembuangan air limbah dengan kejadian diare pada balita di Desa Kecila Kecamatan Kemranjen Kabupaten Banyumas. Nilai OR sebesar 10,967 artinya balita yang tinggal di rumah dengan kondisi pembuangan air limbah pada kategori cukup baik berisiko menderita diare 10,967 
kali lebih besar dibandingkan balita yang tinggal di rumah dengan pembuangan air limbah yang baik.

Sarana pembuangan air limbah adalah suatu bangunan yang digunakan untuk membuang air dari kamar mandi, tempat cuci, dapur dan lain-lain bukan dari jamban, dengan persyaratan, bentuk saluran pembuangan air limbah tertutup atau terbuka, kelancaran air limbah, tidak menimbulkan bau dan karakteristik air limbah (Notoatmodjo, 2012).

Saluran pembuangan air limbah yang tidak memenuhi persyaratan berisiko menyebabkan diare pada anggota keluarga terutama balita. Hal ini sesuai dengan fenomena dalam penelitian ini, dimana rumah tangga di Desa Kecila yang memiliki saluran pembuangan air limbah baik sebagian besar balitanya tidak mengalami diare, sedangkan yang memiliki saluran pembuangan air limbah tidak baik angka kejadian diare pada balitanya lebih tinggi.

Air limbah rumah tangga harus dikelola sedemikian rupa agar tidak menjadi sumber penularan penyakit. Sarana pembuangan air limbah yang tidak memenuhi syarat akan menimbulkan bau, mengganggu estetika dan dapat menjadi tempat perindukan nyamuk dan bersarangnya tikus. Kondisi ini dapat berpotensi menularkan penyakit seperti leptospirosis, filariasis untuk daerah yang endemis filaria. Bila ada saluran pembuangan air limbah di halaman, secara rutin harus dibersihkan, agar air limbah dapat mengalir, sehingga tidak menimbulkan bau yang tidak sedap dan tidak menjadi tempat perindukan nyamuk (Kemenkes RI, 2011).

Hasil penelitian ini sejalan dengan penelitian Hamzah (2012) yang menyatakan bahwa pengelolaan air limbah berhubungan dengan kejadian diare di Kecamatan Belawa Kabupaten Wajo tahun 2012 (p = 0,000). Hasil penelitian Mansyah (2005), juga diperoleh ada hubungan antara faktor kondisi tempat pencemaran air dengan kejadian diare pada balita.

3. Hubungan kondisi jamban keluarga dengan kejadian diare pada balita

Berdasarkan pada tabel 2 diketahui bahwa kondisi jamban keluarga pada kategori cukup baik sebagian balita menderita diare (86,2\%) dan pada kategori baik sebagian besar balita tidak menderita diare (64,0\%). Hasil uji Chi Square diperoleh nilai $p$ value sebesar 0,000 yang lebih kecil dari $\alpha=0,05$ artinya ada hubungan antara kondisi jamban keluarga dengan kejadian diare pada balita di Desa Kecila Kecamatan Kemranjen Kabupaten Banyumas. Nilai OR sebesar 11,111 artinya balita yang tinggal di rumah dengan kondisi jamban keluarga pada kategori cukup baik berisiko menderita diare 11,111 kali lebih besar dibandingkan balita yang tinggal di rumah dengan jamban keluarga yang baik.

Jamban merupakan tempat pembuangan tinja atau air seni pada rumah tangga atau beberapa lembaga. Menurut Wibowo (dalam Wulandary, 2009), bahwa tempat pembuangan tinja yang tidak memenuhi syarat sanitasi akan meningkatkan risiko terjadinya diare pada anak balita sebesar dua kali lipat dibandingkan dengan keluarga yang mempunyai kebiasaan membuang tinjanya yang memenuhi syarat sanitasi.

Jamban keluarga adalah salah satu bagian yang dipergunakan untuk membuang tinja atau kotoran manusia bagi keluarga yang lazim disebut kakus/WC jamban keluarga bermanfaat untuk mencegah terjadinya penularan penyakit dan pencernaan dari kotoran manusia. Adapun syarat jamban sehat adalah tidak berbau dan tinja tidak dapat dijamah oleh serangga dan tikus, tidak mencemari tanah sekitar, sudah dibersihkan, aman dipergunakan, dilengkapi dinding dan atap pelindung, cukup penerangan, lantai kedap air, jamban berbentuk leher angsa, tersedia alat pembersih jamban, lubang penampung kotoran tertutup (Notoatmodjo, 2012).

Data penelitian ini menunjukkan bahwa balita pada rumah tangga yang jenis jambannya baik sebagian besar tidak mengalami diare dan sebaliknya balita pada rumah tangga yang jenis jambannya tidak baik sebagian besar mengalami diare. Hal tersebut mengindikasikan bahwa jenis jamban keluarga berhubungan dengan kejadian diare pada balita, karena balita yang mengalami lebih banyak pada keluarga yang jenis jambannya tidak baik.

Hasil penelitian ini sejalan dengan penelitian Bumulo (2012) yang menyatakan bahwa jenis jamban keluarga yang digunakan ada hubungan dengan kejadian diare pada anak balita $(p=0,000)$. Hasil penelitian ini juga mendukung hasil penelitian lainnya yang dilakukan Fajriana (2012) yang menyatakan ada ada hubungan yang signifikan antara perilaku kepatuhan pemakaian jamban terhadap kejadian diare pada balita ( $p=0,002)$. Hasil ini juga diperoleh hasil yang sama dengan penelitian Hamzah (2012), yang menyatakan ada hubungan penggunaan jamban dengan kejadian diare pada balita $(\mathrm{p}=0,000)$.

4. Hubungan perilaku pemanfaatan sanitasi dasar keluarga balita dengan kejadian diare pada balita

Berdasarkan pada tabel 2 diketahui bahwa perilaku pemanfaatan sanitasi dasar keluarga balita pada kategori cukup baik sebagian balita menderita diare $(87,1 \%)$ dan pada kategori baik sebagian besar balita tidak menderita diare (65,8\%). Hasil uji Chi Square diperoleh nilai $p$ value sebesar 0,000 yang lebih kecil dari $\alpha=0,05$ artinya ada hubungan antara perilaku pemanfaatan sanitasi dasar keluarga balita dengan kejadian diare pada balita di Desa Kecila Kecamatan Kemranjen Kabupaten Banyumas. Nilai OR sebesar 12,960 artinya balita yang tinggal di rumah dengan perilaku pemanfaatan sanitasi dasar keluarga balita pada kategori cukup baik berisiko menderita diare 12,960 kali lebih besar dibandingkan balita yang tinggal di rumah dengan perilaku pemanfaatan sanitasi dasar keluarga balita yang baik. 
Pemanfaatan sanitasi dasar dengan baik dapat menghindarkan keluarga dari berbagai resiko penyakit. Sanitasi dasar permukiman adalah sanitasi minimum yang diperlukan untuk menyediakan lingkungan sehat yang memenuhi syarat kesehatan yang menitikberatkan pada pengawasan berbagai faktor lingkungan yang mempengaruhi derajat kesehatan manusia. Upaya sanitasi dasar meliputi penyediaan air bersih, pembuangan kotoran manusia (jamban), saluran pembuangan air limbah (Azwar, 1999).

Fenomen dalam penelitian ini menunjukaan bahwa balita pada rumah tangga yang perilakunya dalam pemanfaatan sanitasi dasar baik sebagian besar tidak mengalami diare sedangkan balita pada rumah tangga yang perilakunya dalam pemanfaatan sanitasi dasar tidak baik sebagian besar mengalami diare. Hal tersebut mengindikasikan bahwa perilaku pemanfaatan sanitasi dasar berhubungan dengan kejadian diare pada balita, karena balita yang mengalami diare lebih banyak pada rumah tangga yang perilakunya dalam pemanfaatan sanitasi dasar tidak baik.

Hasil penelitian ini sejalan dengan hasil penelitian Hamzah (2012), yang menyatakan ada hubungan kebiasaan ibu mencuci tangan dengan air bersih dan sabun dengan kejadian diare pada balita $(\mathrm{p}=$ 0,009). Hasil penelitian ini juga sama dengan penelitian Bumulo (2005), yang menyatakan ada ada pengaruh prilaku mencuci tangan terhadap kejadian diare $(p=0,034)$.

Hasil penelitian lainnya oleh Sirait (2010), juga menyatakan ada hubungan perilaku hidup bersih dan sehat ibu dengan kejadian diare pada anak usia 1-4 tahun ( $\mathrm{p}=0,000)$. Hal ini dikarenakan perilaku ibu baik menyangkut pengetahuan, sikap dan tindakan yang mencerminkan hidup bersih dan sehat menjadikan lingkungan sekitar rumah ibu selalu bersih dan tempat makanan serta minuman juga terjaga kebersihannya sehingga tidak menjadi tempat kuman dan bakteri berkembang biak.

\section{KESIMPULAN DAN SARAN \\ Simpulan}

Hasil penelitian dapat disimpulkan ada hubungan antara kondisi dan perilaku pemanfaatan sanitasi dasar dengan kejadian diare pada balita di Desa Kecila Kecamatan kemranjen Kabupaten Banyumas.

Saran

Warga masyarakat lebih memperhatikan kondisi lingkungan rumah yang baik, dengan membersihkan SPAL agar dapat berfungsi baik, menggunakan jamban leher angsa dan membersihkan jamban minimal 1 kali seminggu dan memanfaatkan sanitasi dasar dengan sebaik-baiknya dan meningkatkan perilaku yang sehat seperti dengan selalu mencuci tangan sebelum memberikan makan anaknya, air yang dikonsumsi selalu di masak terlebih dahulu dan peralatan makan dan minum di cuci dari air yang mengalir. Instansi kesehatan lebih meningkatkan upaya penyuluhan tentang pentingnya kondisi lingkungan rumah yang sehat dan pemanfaatannya, khususnya dalam rangka mencegah terjadinya diare pada balita, Peneliti lain perlu mengembangkan lebih lanjut dengan meneliti pengaruh kondisi dan perilaku pemanfaatan sanitasi dasar terhadap penyakit berbasis lingkungan lainnya seperti pneumonia.

\section{UCAPAN TERIMA KASIH}

Terima kasih disampaikan kepada Kepala Desa Desa Kecila Kecamatan kemranjen dan Jurusan Kesehatan Lingkungan Politeknik Kesehatan Kemenkes Semarang, sehingga penelitian dapat terselesaikan.

\section{DAFTAR PUSTAKA}

Adisasmito W. 2007. Faktor Risiko Diare Pada Bayi Dan Balita Di Indonesia : $\quad$ Systematic Review Penelitian Akademik Bidang Kesehatan Masyarakat. Makara, Kesehatan, Vol. 11, No. 1, Juni 2007:1-10.

Arikunto, S. 2006. Prosedur Penelitian Suatu Pendekatan Praktik. Jakarta: Rineka Cipta.

Azwar, A. 1999. Pengantar Administrasi Kesehatan. Jakarta : Binarupa Aksara.

Bumulo, S. 2012. Hubungan Sarana Penyediaan Air Bersih Dan Jenis Jamban Keluarga Dengan Kejadian Diare Pada Anak Balita Di Wilayah Kerja Puskesmas Pilolodaa Kecamatan Kota Barat Kota Gorontalo Tahun 2012. http://ejurnal.fikk.ung.ac.id/index.php/PHJ/article /download/139/62.

Balitbang Kimpraswil. 1999. Spesifikasi Sumur Gali Untuk Sumber Air Bersih. Jakarta : Balitbang Kimpraswil.

Chandra, B. 2007. Pengantar Kesehatan Lingkungan. Penerbit Buku Kedokteran (EGC), Jakarta

Dahlan, Sopiyudin M, 2008. Langkah-Langkah Membuat Proposal Penelitian Bidang. Kedokteran dan Kesehatan. Jakarta : Sagung Seto.

Depkes RI. 2005. Buku Pedoman Pelaksanaan Program P2 Diare. Jakarta : Depkes RI

Departemen Kesehatan RI, 2008. Strategi Nasional Sanitasi Total Berbasis Masyarakat. Jakarta; Depkes RI.

2011. Buletin Jendela Data dan Informasi Kesehatan Volume 2 Triwulan 2. Jakarta; Depkes RI. 
Entjang I. 2000. Ilmu Kesehatan Masyarakat. Jakarta : Citra Aditya Bakti

Fajriana A.R.. 2012 Hubungan Kepemilikan Jamban Dengan Kejadian Diare Pada Balita Di Desa Jatisobo Kecamatan Polokarto Kabupaten Sukoharjo.

http://eprints.ums.ac.id/22301/12/10_naskah_publ ikasi.pdf

Gustiana S. 2013. Hubungan Perilaku Ibu dengan Kejadian Diare pada Balita di RW 07 Tomang Mandala Jakarta Barat Tahun 2013. http://digilib.esaunggul.ac.id/hubungan-perilakuibu-dengan-kejadiandiare-pada-balita-di-rw-07tomang-mandalajakarta-barat-tahun-2013833.html

Hamzah, B. 2012. Hubungan Perilaku Hidup Bersih Dan Sehat Dengan Kejadian Diare Pada Balita Di Kecamatan Belawa Kabupaten Wajo Tahun 2012.

http://repository.unhas.ac.id/bitstream/handle/123 456789/4340/HAMZAH_K11109015.pdf?sequen $\underline{\mathrm{ce}=1}$

Kemenkes RI, 2011. Buletin Penyakit Menular. Jakarta: Kemenkes RI.

2011. Pengendalian Diare D Indonesia. Jakarta : Kemenkes RI

2012. Situasi Diare Di Indonesia. Jakarta : Kemenkes RI

Tahun 2013. Jakarta: Kemenkes RI.

Mansyah. 2005. Beberapa Faktor Yang Berhubungan Dengan Kejadian Diare Balita Di Desa Sigayam Wilayah Kerja Puskesmas Wonotunggal Kabupaten Batang. http://eprints.undip.ac.id.

Notoatmodjo, S. 2005. Metodologi Penelitian Kesehatan, Rineka Cipta, Jakarta

2005. Ilmu Kesehatan Masyarakat Prinsip-Prinsip dasar. Jakarta : Rineka Cipta

2012. Promosi Kesehatan dan Ilmu Perilaku. Jakarta: Rineka Cipta

Ngastiyah. 2005. Perawatan Anak Sakit Jakarta:EGC
Nursalam. 2012. Konsep dan Penerapan Metodelogi Penelitian Ilmu Keperawatan Pedoman Skripsi, Tesis, dan Instrumen Penelitian Keperawatan. Jakarta: Salemba Medika.

Pitono.A.J,Dasuki, Ismail. 2008. Penatalaksanaan Diare Di Rumah Pada Balita. Berita Kedokteran Masyarakat. Vol.22.no.1.maret 2006:7-14

Sirait A. Faktor-faktor yang Berhubungan Dengan Kejadian Diare Pada Balita di Desa Simanabun Kec. Silou Kahean Kabupaten Simalungun Tahun $2010 . \quad$ http://sari-mutiara.ac.id/new/wpcontent/uploads/2013/10/simalungun

Sudarmo SM. 2007. Diare Akut Anak Dalam Ilmu Penyakit Anak Diagnosa Dan Penatalaksanaan. Jakarta: Salemba Medika.

Suharyono. 2008. Diare Akut, Klinik dan Laboratorik. Jakarta: Rineka Cipta.

Suliha U. 2013. Pendidikan Kesehatan Dalam Perawatan. Jakarta : EGC

Suraatmaja S.2007. Kapita Selekta Gastroentrologi. Jakarta: Sagung Seto

Santjaka A, 2008. Statistik Untuk Penelitian Kesehatan. Yogyakarta : Nuha Medika

Sasongko, dr, Rahardiyan. 2009. Petunjuk Modern Kesehatan Keluarga. Yogyakarta: Panji Pustaka

Soeparman dan Suparmin. 2002, Pembuangan Tinja dan Limbah Cair, Jakarta. EGC.

Sugiyono, 2008. Metode Penelitian Kuantitatif Kualitatif dan R7D Bandung Alfabeta

Widoyono, 2008. Penyakit Tropis Epidemiologi, Penularan, Pencegahan Dan Pemberantasannya. Surabaya : Erlangga.

Wisnu AW. 1999. Dampak Pencemaran Lingkungan. Andi Offset. Yogyakarta.

Wulandari A. P. 2009. Hubungan Antara Faktor Lingkungan Dan Faktor Sosiodemografi Dengan Kejadian Diare Pada Balita Di Desa Blimbing Kecamatan Sambirejo Kabupaten Sragen Tahun 2009.

http://etd.eprints.ums.ac.id/5960/1/J410050008.P DF 